\title{
11. Metaphor use in the political communication of major resource projects in Australia
}

Abstract: This article explores the patterns of political communication surrounding the environmental regulation of major Australian resource projects during the Business Advisory Forum of April 2012. The Forum discussed business and government responses to major project approvals to improve national productivity at a time when these projects also posed significant implications for anthropogenic global warming. The article's method is to examine print news articles published during this period. While the international literature has long demonstrated how the American fossil fuel lobby has employed metaphor to characterise climate change as a 'non-problem'-therefore allegedly making regulation of greenhouse gas emissions economically and politically unnecessary - no Australian study of metaphor use in climate science news has been conducted. This article, in finding news stories on so-called 'green tape' environmental regulation were saturated with metaphor clusters, argues that journalistic metaphor use has made the complex issue of environmental regulation accessible to mass audiences. But, in so doing, we also argue this metaphor use has supported business and government's position on environmental deregulation of major projects. Finally, this article also argues that some journalists' use of metaphors encouraged policy-makers to adopt, and re-use, journalists' own language and, in so doing, allow those journalists to be seen as complicit in the shaping of softer public attitudes to the impact of major projects on anthropogenic climate change.

Keywords: agenda setting, Australia, climate change, deregulation, emissions, environmental journalism, fossil fuel lobby, greenhouse gas, metaphor, newspapers, rhetoric

\author{
GUY HEALY \\ Queensland University of Technology
}

PAUL WILLIAMS

Griffith University 


\section{Introduction}

T HAS long been a truism that those who control political language also control policy outcomes. Ancient and modern scholars have argued that the scrutiny of political leaders' language offers invaluable insight into how public opinion is shaped. This, in turn, offers scholars an understanding of how liberal democratic leaders 'purchase' mandates to steer public policy (Stockwell, 2005, p. 35; Nisbet \& Huge, 2006). Moreover, scholars have known at least since the time of Aristotle and Plato that rhetoric - the 'manipulation of signs and symbols for influence and effect' (Brummett, 2003) to influence the behaviour of others-is the most effective non-violent form of mass persuasion. Intuitively, in a digital age defined by 24-hour news cycles, ubiquitous social media and an explosion in political public relations, the study of rhetoric has never been more germane. Understanding the language devices used by political actors - state and party leaders as well as those who seek to influence policy debate, for example, pressure group leaders - is essential to understanding how changes to public policy can be 'sold' to citizens and the news media.

The science of rhetoric - establishing truths or proofs to aid rational argument and political deliberation-was first systemised by Aristotle (Stockwell, 2005, p. 37), who detailed three forms of persuasion, or 'proof': ethos (established through the character of the speaker), pathos (established by emotional appeals to the audience), and logos (established by logical presentation of the facts) (Rapp, 2010). Accordingly, Aristotle regarded metaphor use as a key element of rhetoric that assisted speakers in effective, and appealing, communication (Stockwell, 2005, p. 42; Rapp, 2010). Moreover, the most persuasive rhetoric is brief (Plato, 380BCE; Thibodeau \& Boroditsky, 2011, p. 1). Accordingly, proofs-either subjective or objective truths - can be established in 'tropes', 'memes' or other concise statements easily transmitted, repeated and understood-by an often under-informed or disengaged public (Toncar \& Munch, 2003). In an emerging 'post-truth' political milieu (Stone \& Kuznick, 2013, p. 532), understanding how political language can be manipulated for policy outcomes has therefore never been more critical.

The role of resource-rich pressure groups in shaping public policy, either directly through advertising or indirectly through news media agenda-setting, must also be considered, especially when the signs and symbols of political language of powerful sectional groups can become more persuasive than objective facts. Anthropogenic made climate change is a case in point: heavy carbon-producers enjoy an interest in steering government policy away from punitive carbon taxes - regardless of the scientific consensus on climate change - and instead toward policies that maintain fossil-fuel dependencies.

Hall et al (2013, p. 57) have argued that a key mechanism by which power is exercised is via the 'interpretations' of social events offered by the media, that 
is, through 'primary definers' (sources) and 'secondary definers' (journalists). Declining newsroom resources too often mean primary institutional sources are 'over-accessed' by 'secondary definers' and this, in turn, risks 'reproducing the definitions of the powerful.' Additionally, Hall et al (2013, p. 59) argue that news outlets use their editorial, or 'public idiom', to campaign openly for reforms, and often where class interests are represented as the interests of the general public. Moreover, despite a Fourth Estate commitment to objectivity that requires the news media to balance its sources, 'certain strategic areas of silence' can emerge which can, for example, restrict the range of solutions the news media might print or broadcast during a dispute, or even 'render them invisible' (Westergaard in Hall et al, p. 65).

An increasingly common term is 'junk' science: itself a powerfully concise metaphor designed to confuse public understanding of the science of global warming and to shape public opinion on government responses to climate change (Herrick \& Jamieson, 2001, p. 14; Jacques, Dunlap \& Freeman, 2008, p. 349). Critically, American fossil fuel corporations have co-opted such metaphors as 'junk' science, and even Hippocrates' 'Do no harm' has been mooted as a call to resist carbon regulation (McCright \& Dunlap, 2000 p. 510; Livesey, 2002, p. 128). Some conservative bloggers go further and describe climate change as 'myth', 'gospel' or 'bible' to support the over-arching metaphor of 'science as religion' (Nerlich, 2010, p. 419). Yet it is important to note that moralism is hardly partisan in this debate: former Labor Prime Minister Kevin Rudd, for example, framed much of his campaign for the 2007 federal election around climate change representing the 'great moral challenge of our generation' (Rudd 2007; Williams 2008, p. 113).

\section{Metaphor}

Metaphor is at the heart of political persuasion. According to Stockwell (2005, p. 42), Aristotle (1991, p. 1410) regarded the metaphor as 'the archetype of human communication' because this rhetorical tool enables speakers to communicate their arguments with 'swift understanding'. Underpinning metaphor use is the process of 'framing' which produces 'symbolic devices' such as metaphors, catchphrases, stereotypes and vivid visual images (Gamson \& Modigliani in de Vreese, 2012, p. 367; Entman, 1993, p. 52; Pan \& Kosicki, 1993, p. 56). Lakoff and Johnson (1980, p. 3), for example, found that metaphors are not merely poetically ornamental but essential to everyday functioning: human cognition is 'fundamentally metaphorical in nature'. It is, therefore, the metaphor's power to penetrate human cognition that comprises the core of this article.

Lakoff and Johnson (1980, p. 4) argue that personified metaphor is used to better communicate abstract elements of an argument to relate more easily to readers' instances of personal or physical conflict. Typical economic examples 
include 'inflation has attacked the foundation of our economy' and 'our biggest enemy right now is inflation' (Lakoff \& Johnson, 1980, p. 33). The elegance of personified metaphors is their offer not only of a 'specific way of [abstract] thinking' but also a 'way of acting toward [a solution]' which, in turn, can justify contentious political action (Lakoff \& Johnson, 1980, p. 34). More specifically, Miles, Huberman \& Saldana (2013, p. 281) argue that metaphors act both as literary and 'data-condensing' devices. For example, Krennmayr (2015, p. 542) found greater numbers of metaphors are required in newspapers 'to explain complex situations and concepts' to non-expert readers. Moreover, in a phenomenon known as 'reasoning by policy metaphor', other cognitive studies have shown how news metaphors can shape consumers' positions on complex policy issues such as health and crime, even - or perhaps especially — when consumers possess low knowledge, or are unaware of the covert nature of metaphor use (Schlesinger \& Lau, 2000, p. 611; Thibodeau \& Boroditsky, 2011, p. 16782). As Rowinski (2014, p. 9) argues, this succeeds because political metaphors allow consumers to justify unorthodox views on contentious issues which, in turn, can legitimise political actors' policy choices. Bates offers a deeper explanation of the 'method in the metaphor' which, he argues, allows leaders to employ rhetorical strategies that, in drawing upon metaphor clusters, work in tandem to achieve political objectives. US President George H. Bush's Persian Gulf War rhetoric in 1990, for example, drew on savagery and civilisation metaphors (Bates, 2004, p. 455) where the former problematised the crisis and the latter justified what appeared to be an auspicious solution. Frequent repetition of 'antithetical' metaphor clusters can also increase persuasiveness (Bates, 2004).

\section{Significance of this study}

A study of metaphor use in the communication of major resource project approvals and attendant public policy is timely given both the climate emergency and increased scholarly interest in metaphor use. This is critical as the international science community reaches a near perfect consensus as to the extent of humanity's role in global warming (Walther et al 2005; Stocker et al, 2013, p. 17; NASA, 2016). Perversely, despite what is probably the 'largest scientific assessment exercise in history' (Woodward et al 2014), public consensus on climate change trails that required for meaningful government responses (Gibson et al, 2015). Indeed, climate science scepticism is so noisily articulated that even moderate western governments are slow to adopt economically challenging solutions (Jacques, Dunlap \& Freeman 2008, p. 349; Tranter \& Booth, 2015, p. 163; Dayrell et al, 2016). Profits and losses by major infrastructure corporations are also important drivers of government policy but here, too, vivid metaphor has arguably played a salient role in delegitimising regulation. For example, during Australia's mining tax debate in 2010, the mining lobby effectively defeated the 
Rudd Government's Resource Super Profits Tax, partly via the lobby's strategy of claiming 'the tax is the equivalent of killing the goose that lays the golden egg' (McKnight \& Hobbs, 2013, p. 311).

In what superficially appears to be an abrogation of Fourth Estate principles, international studies show that news and wire outlets use increasingly fewer scientific sources in climate change news reports - a dearth which permits the dissemination of misinformation (Trumbo, 1996, p. 281; Boykoff \& Boykoff, 2004, p. 134; Antilla, 2005, p. 350). Similar trends in the politicisation of climate science via news media have been observed in Australia (Bacon \& Nash, 2012; McGuarr, Lester \& Painter, 2013) and the Pacific (Robie, 2014). Fortuitously, the scholarly literature is replete with research on metaphor use in the news media, with Anderson (2002), for example, citing references of Hillary Clinton as Madonna. Significant Australian studies have also been done on such vexing social problems as Indigenous health (Brough, 1999), immigration (Burke, 2002), asylum-seekers (Saxton, 2003), Lebanese youth gangs (Noble \& Poynting, 2003), heroin abuse (Watts, 2003), methadone treatment (Fraser, 2006), and 'boat people' (McKay, Thomas \& Blood, 2011). However, far less research has been conducted internationally on metaphor use in the reporting of environmental regulation and climate science - Lakoff (2010) and Luokkanen, Huttunen \& Hildén (2014) are among the few - while no research has been conducted in Australia. This article offers to fill this need through an analysis of metaphor use in the Australian reporting — within a climate change and human health frame - of major resource project news. As such, this article argues that journalistic metaphor uses by print journalists and Australian Associated Press (AAP) during the 'green tape' 'crisis' of 2012 made this complex issue accessible to mass audiences. But, in employing metaphors - almost half of which favourably framed business and government positions on environmental deregulation - journalists failed to uphold their Fourth Estate principles of objectivity and neutrality. Given that some journalists' liberal use of metaphor in turn shaped the public narrative by encouraging policy-makers to adopt and re-use journalists' own language, it can be further argued that some journalists were at least tacitly complicit in the shaping of softer public attitudes to the impact of major projects on anthropogenic climate change.

\section{Method}

This research adopts a mixed-methods approach designed to reconcile epistemological and ontological issues arising from the joint use of interpretivist and objectivist methodologies (Miles \& Huberman in Onwuegbuzie \& Leech, 2005 , p. 377). The research design draws on standard international journalism methods including interviews with participants, content analysis and an original Freedom of Information request. This article, however, presents only the most significant results from the content analysis-based metaphor research. 
The Business Advisory Forum of the Council of Australian Government's (COAG) meeting of April, 2012, was chosen as a 'politically important' and 'information rich' case (Onwuegbuzie \& Collins, 2007). As such, it sits comfortably within Miles \& Huberman's typology (Onwuegbuzie \& Collins, 2007). This article aims to determine why the 'green tape' term increased in use, what journalists understood by the term 'green tape', and whether journalists challenged, or contributed to, the term's wider adoption as a seemingly neutral synonym for environmental regulation. The final sample is based upon a Factiva search of all Australian newspapers and AAP articles for the period April, 2012, using the search string 'green tape'. Crucially, the prevalence of personified metaphors found in 'green tape' stories encouraged the authors to develop original taxonomies, as suggested by Bourdieu (2005), to analyse rhetorical structures in the news. According to Bourdieu, the first task of the researcher when dealing with journalists - as the 'visible agents' of political leaders - is to make explicit via taxonomies the authorities' implicit rhetorical schemes (Bourdieu, 2005, p. 38). In simple terms, Bourdieu invoked Plato who demanded the 'strings' of the 'puppets' be identified. This is considered essential given journalists 'are manipulated as much as they manipulate': a phenomenon described as the 'evil circle of information' (Bourdieu, 2001, p. 246; Bourdieu in Petersen, 2003, p. 253).

\section{The 'green tape' crisis of April, 2012}

The formidable power of the resource sector's political communication in Australia has been well established (Tsokhas, 1998; Pearse, Burton, \& McKnight, 2013; McKnight \& Hobbs, 2013; Marsh, Lewis \& Chesters, 2014). In separate studies, Macintosh (2009) and McGrath (2014) assessed the merits of the Environment Protection \& Biodiversity Conservation Act 1999 (EPBC) regarding global warming and the regulation of resources projects. Matters of National Environmental Significance (MNES), such as World Heritage Areas, the Great Barrier Reef, migratory species and internationally important wetlands were specifically analysed. Little is known, however, about the political communication of major infrastructure and resource projects in Australia, or about the discourse surrounding the $E P B C$ in its regulation of major projects, including how fossil energy use drives global warming (DEA, 2013, p. 24; Macintosh, 2009, p. 341; Harris et al, 2009). A landmark change to this environmental regulation in Australia in 2012, discussed below, serves as a useful case study.

Liberal Prime Minister John Howard introduced the EPBC in 1999 to delineate the responsibilities of the three levels of government, and to avoid replicating the legal disputes of the famous Tasmanian Dams Case of 1983. However, in the wake of the Global Financial Crisis, the key pressure group the Business Council of Australia (BCA) told the Commonwealth Government this Act jeopardised $\$ 900$ billion in major projects and required urgent 'streamlining' (BCA, 2012, 
p. 5). The issue came to a head at the inaugural Business Advisory Forum of April, 2012, convened by Labor Prime Minister Julia Gillard, whose assembly of the Forum's 25 business leaders coincided with a COAG meeting. Gillard had warned that excessive regulation, or 'red tape', was impeding productivity, and a Forum was required to hear directly from major businesses (Bradbury, 2012). Not unexpectedly, the BCA had long characterised the often conflicting business regulations under Australia's nine governments as the 'dead hand of red tape' (Shepherd, 2012). Critically, business leaders, the federal Coalition opposition, conservative state premiers and much of the news media described Commonwealth oversight of major projects under the Act as both 'red' and 'green tape': a form of bureaucratic regulation impeding major projects. Interpretations of events at the Forum vary, but significant approval powers over major projects were handed to the states in principle. Unreported until now, the authors can reveal the terms of a landmark BCA/Commonwealth plan-to withdraw the Commonwealth from significant environmental oversight - was secretly struck prior to the Forum (FOI/2015/240). While the BCA hailed the deal as a 'great leap forward' (Shepherd, 2012), the Wentworth Group of Concerned Scientists said the Commonwealth's withdrawal set 'environmental policy in Australia back decades' (WGCS, 2012) and, importantly, had been conducted without any community consultation. Similarly, Doctors for the Environment contested the issue, and described the 'green tape' phrase as dangerous rhetoric that masked identification of adverse health impacts from major projects (DEA, 2013, p. 18). Indeed, Australian scholars have found state governments successfully hindering, sanitising or delaying public health and environmental research, with harmful exposures in the environment the third most suppressed type of research in Australia (Yazahmeidi \& Holman, 2007, p. 553).

\section{Results}

Content analysis of 'green tape' stories from the Forum offer six main findings. First, newspapers saw the Forum, and the political fallout from the meeting, as eminently newsworthy, with 90 'green tape' stories (67 of them 'hard' news) written in just 13 days. News coverage peaked in the week of the Forum, which also saw COAG confirm the Forum's agreement to hand significant powers to the states. Coincidentally, the Greens' federal leader Dr Bob Brown resigned at this time. Importantly, Opposition leader Tony Abbott adopted the BCA's full proposal as Coalition environment policy the following week. Second, in important expressions of their 'public idiom' (Hall et al, 2013), the rival News Corp and Fairfax stables considered the Forum deliberations significant, and published editorials in The Australian, The Age and The Sydney Morning Herald. Both The Australian and The Sydney Morning Herald editorialised with their own personified metaphors to describe environmental regulation. In the 
context of an example of the BCA's use of 'green tape', The Sydney Morning Herald wrote how 'all the hydra heads belong to the same snake.' Similarly, The Australian opined that 'green tape' was 'tying business in knots', while The Age dismissed 'green tape' as 'political spin' designed to help 'shred' environmental regulation by making it 'indefensible.' Third, the bulk of 'green tape' coverage was conducted by the country's three agenda-setting national news outlets, The Australian, AAP and the Australian Financial Review (AFR), although The Age, The Sydney Morning Herald, The Courier-Mail and The Daily Telegraph also provided significant coverage. Fourth, Forum decisions were not a 'beltway' issue: rural and regional newspapers, which consume $A A P$ copy and serve regional audiences in major resource project areas (McLachlan, 2013 , p. 13) also ran significant numbers of 'green tape' stories. Fifth, and consistent with Hall et al's concept of 'public idiom', journalists made in their stories 18 references to jobs and job creation under major projects.

Sixth, and most importantly, MNES received modest coverage across the 90 news and opinion articles despite the important implications of the deregulation of major project approvals on both global warming and human health. Content analysis of 90 stories showed 40, or almost half, neglected to mention environmental values. Of the other 50, journalistic balance was shown in the 47 mentions of MNES. Among these, 23 mentioned the potential impact on 'World Heritage Areas', 11 to the Act itself, six to the Great Barrier Reef, four to uranium mining and uranium reactors, and three to the Murray Darling Basin and wetlands. Crucially, there were just 11 references to global warming or climate change in the total 90 story sample, but just four in news stories and, of these, two were in the context of the regulatory burden on business. There were just six references to potential impacts on national parks. Despite the climate and health impacts of major projects (Macintosh, 2009; Harris et al, 2009; DEA, 2013), there were only four references to human health impacts, and only two of these in news stories.

\section{A taxonomy of metaphor use in 'green tape' news stories}

The article now turns to an analysis of the normalisation of the term 'green tape' via a set of original taxonomies. Given hard news stories often rely on metaphor to better communicate abstract concepts (Krennmayr, 2015), this research finds that news reports of Forum proceedings were saturated with additional metaphors that shaped - along four lines - the narratives of the competing proregulation 'For', and anti-regulation 'Against', cases.

Four key points emerge. First, 130 metaphors, in addition to 'green tape' and 'red tape' references, were found in the 67 news stories, or almost two per story. Second, metaphors were most commonly found-by a factor of over three to one - in journalists' paraphrasing outside interviewee quotes. Third, almost half the metaphors described the claims and counterclaims of protagonists, usually in 
personified and violent terms. Fourth, the metaphors exhibited six themes. Consistent with Bourdieu (2005), these themes have been developed into a taxonomy: (1) constraint; (2) suffering fatal violence or injury; (3) war and fighting; (4) euphemism; (5) suffering obstacles, and (6) deception. This original taxonomy is now anatomised.(1) The constraint metaphor cluster was coded from metaphors used by journalists to describe how environmental regulation impedes major projects regarding costs and delays to resource and infrastructure developers. The suffering fatal violence and injury cluster was coded from metaphors used by journalists in two ways: first, in their own words to describe what regulations were doing to developers and their projects; and, second, in interviewee quotes from political and business sources chosen to describe what regulations were doing to major projects, and infrastructure developers. The war and fighting cluster was coded from metaphors used by outlets in two ways: first, to describe how regulation should be treated, and why; and, second, to describe the claim and

\begin{tabular}{|c|c|c|}
\hline Metaphor cluster & $\begin{array}{l}\text { Metaphor } \\
\text { (occurrence) }\end{array}$ & Examples \\
\hline Constraint & $\begin{array}{l}\text { Tie up economy/ } \\
\text { project (3) } \\
\text { Burden (3) } \\
\text { Hobbling projects (1) } \\
\text { Clogging (1) } \\
\text { Ballooning (1) } \\
\text { Drain on economy (1) }\end{array}$ & $\begin{array}{l}\text {...a mine, port, rail line or tourist pro- } \\
\text { ject must meet state and federal envi- } \\
\text { ronmental rules, which can tie up the } \\
\text { project for years. (Cut green tape in de- } \\
\text { velopment. AAP, } 13 \text { April, 2012) }\end{array}$ \\
\hline $\begin{array}{l}\text { Suffering } \\
\text { violence }\end{array}$ & $\begin{array}{l}\text { Strangling (3) } \\
\text { Tortuous (2) } \\
\text { Hamstrung (1) } \\
\text { Threatened (1) } \\
\text { Suffocated (1) } \\
\text { Choking (1) }\end{array}$ & $\begin{array}{l}\text {...COAG Business Advisory Forum to } \\
\text { streamline the way in which major } \\
\text { projects are assessed for their environ- } \\
\text { mental impact and cut other red tape } \\
\text { which is strangling business. (Training, } \\
\text { green tape moves at COAG, AAP } 13 \\
\text { April) }\end{array}$ \\
\hline War and fighting & $\begin{array}{l}\text { War (2) } \\
\text { Unwieldy (2) }\end{array}$ & $\begin{array}{l}\text { Companies urge war on 'green tape' } \\
\text { (The Australian, } 11 \text { April) THE business } \\
\text { community has united to demand Julia } \\
\text { Gillard and the state premiers slash un- } \\
\text { wieldy environmental assessments and } \\
\text { approvals processes, warning 'green } \\
\text { tape' is jeopardising } \$ 900 \text { billion in re- } \\
\text { sources and infrastructure projects }\end{array}$ \\
\hline
\end{tabular}

Note: News reports coded according to manifest position of the protagonist as either 'Against' or 'For' the continuation of Commonwealth regulation of major projects under the EPBC Act. See primary references for citations 
counter-claim of protagonists in the 'green tape' field. The euphemism cluster was coded from metaphors used by journalists, business people and politicians to describe how regulations can be changed, and why. The suffering obstacles cluster arose from metaphors in government and business interviewee quotes that describe impacts on developers, and the economy. The deception cluster arose from metaphors used by journalists in interviewee quotes from conservationists. Importantly, these 20 euphemistic metaphors presented the deregulation case in auspicious terms.

\begin{tabular}{|l|l|l|}
\hline \multicolumn{2}{|c|}{ Table 2: 'Against' metaphor clusters continued (Euphemism) } \\
\hline Metaphor cluster & $\begin{array}{l}\text { Metaphor } \\
\text { (occurrence) }\end{array}$ & Examples \\
\hline & $\begin{array}{l}\text { Streamline (8) } \\
\text { Fast-track (8) } \\
\text { Declutter (2) } \\
\text { Overhaul (1) }\end{array}$ & $\begin{array}{l}\text { GREEN groups have slammed Tony Ab- } \\
\text { bott's policy to strealime environmen- } \\
\text { tal approvals for major projects, warn- } \\
\text { ing that any moves to slash the green } \\
\text { tapes choking development must not } \\
\text { come at the expense of environmental } \\
\text { protections. (The Australian, 21 April) }\end{array}$ \\
\hline
\end{tabular}

Importantly, journalists used large numbers of these personified metaphors of physical conflict to help explain these abstract news events to non-expert readers.

\begin{tabular}{|c|c|c|}
\hline Metaphor cluster & \begin{tabular}{|l|}
$\begin{array}{l}\text { Metaphor } \\
\text { (occurrence) }\end{array}$ \\
\end{tabular} & Examples \\
\hline War and fighting & $\begin{array}{l}\text { Slash (25) } \\
\text { Slam (17) } \\
\text { Cut (12) } \\
\text { Axe (2) } \\
\text { Ran into flak (1) } \\
\text { Backfire (1) } \\
\text { Launch attacks (1) } \\
\text { Targeted (1) }\end{array}$ & $\begin{array}{l}\text { But Senator Brown told the Weekend } \\
\text { Financial Review he believed Labor's } \\
\text { move to open the door to softening } \\
\text { environmental protection laws - to ap- } \\
\text { pease demands for less 'green tape' - } \\
\text { could backfire and help his party. (AFR, } \\
14 \text { April }\end{array}$ \\
\hline
\end{tabular}

Note: Use of personified metaphors of physical conflict in an explanatory context.

The Labor and Opposition leaders, who agreed in principle on this deregulatory change, used these vivid metaphors in bold to communicate their position to the public.

Five key conclusions can be drawn from Tables 1 to 5. First, the results indicate that political and business leaders opportunistically recycled influential journalists' personified metaphors for their own political ends, with those metaphors later quoted prominently by the agenda-setting print media. The personified metaphor 


\begin{tabular}{|c|c|c|}
\hline $\begin{array}{l}\text { Metaphor } \\
\text { cluster }\end{array}$ & $\begin{array}{l}\text { Metaphor } \\
\text { (occurrence) }\end{array}$ & Examples \\
\hline $\begin{array}{l}\text { Suffering } \\
\text { violence and } \\
\text { death }\end{array}$ & $\begin{array}{l}\text { "... killing new projects ..." (2) } \\
\text { "... strangled in a tangled } \\
\text { web of green tape ..." (2) } \\
\text { "... cripple and industry ..." (1) } \\
\text { "... stifling ... "( } 1 \text { ) } \\
\text { "... threatened industries" (1) } \\
\text { "... tortouous" (2) } \\
\text { "... at the mercy" (3) }\end{array}$ & $\begin{array}{l}\text { "The kind of green tape that has } \\
\text { strangled residential development ... } \\
\text { will be slashed under the proposal," } \\
\text { Mr Abbott said. (Green tape slashed } \\
\text { under Coalition plan, AAP, } 20 \text { April) }\end{array}$ \\
\hline $\begin{array}{l}\text { Suffering } \\
\text { obstacles }\end{array}$ & $\begin{array}{l}\text { "undergrowth" (1) } \\
\text { "bedevilled" (1) } \\
\text { "approvals act as brake on } \\
\text { growth" (1) }\end{array}$ & $\begin{array}{l}\text { "Governments can act and clear } \\
\text { this undergrowth of regulation that } \\
\text { doesn't need to be there," the Prime } \\
\text { Minister said. (PM sells skills as red } \\
\text { tape targeted, Canberra Times, } 13 \\
\text { April). }\end{array}$ \\
\hline
\end{tabular}

Note: Where journalists chose to quote metaphors from interviewees, or 'the talent', in support of the 'Against' case.

\section{Table 5: Location of 'for' journalistic metaphors from IVs}

\begin{tabular}{|c|c|c|}
\hline $\begin{array}{l}\text { Metaphor } \\
\text { cluster }\end{array}$ & $\begin{array}{l}\text { Metaphor } \\
\text { (occurrence) }\end{array}$ & Examples \\
\hline $\begin{array}{l}\text { War and } \\
\text { destruction }\end{array}$ & $\begin{array}{l}\text { "... war ..." }(2) \\
\text { "... bulldoze ..." (1) } \\
\text { "... rip ..." (1) } \\
\text { "... stifling ... "(1) } \\
\text { "... new age of environmen- } \\
\text { tal wreckage ..." (1) } \\
\text { "... declare open season" (1) } \\
\text { "... biggest assault ..." (2) }\end{array}$ & $\begin{array}{l}\text {... the push by business has promp- } \\
\text { ted a furious response from Bob } \\
\text { Brown, who accused big business } \\
\text { yesterday of declaring war on the } \\
\text { community because it wanted to } \\
\text { "bulldoze decades of environmental } \\
\text { law" to provide protections to big } \\
\text { miners (The Australian, } 12 \text { April). }\end{array}$ \\
\hline War continued & & $\begin{array}{l}\text { The agreement to speed up environ- } \\
\text { mental assessments is likely to anger } \\
\text { the Greens, who labelled the idea "a } \\
\text { war on the Australian people's qual- } \\
\text { ity of life and the environment by the } \\
\text { big end of town". (Premiers to slash } \\
\text { green tape, SMH, } 12 \text { April). }\end{array}$ \\
\hline Deception & $\begin{array}{l}\text { "Orwellian" (1) } \\
\text { "two-faced" (1) } \\
\text { "water down" (1) }\end{array}$ & $\begin{array}{l}\text { Greens leader Christine Milne said } \\
\text { it was "Orwellian" for Mr Abbott to } \\
\text { claim to be a conservationist while } \\
\text { launching an assault on environmen- } \\
\text { tal protection laws. (AFR, } 21 \text { April) }\end{array}$ \\
\hline
\end{tabular}

Source: Author's own analysis 
strangling, for example, first appears in a journalist's own words, and then later in the source quotes of Federal Liberal leader Abbott and Queensland Liberal-National Party Deputy Premier Jeff Seeney. Similarly, tortuous appears in a journalist's own words, and then in BHP leader Marius Kloppers's quote. Again, War first appears in a headline, and then later in a Greens' MP's direct quote. In short, metaphor use in the 'green tape' field suggests circularity among journalists and politicians. Second, the metaphors enjoying the greatest frequency were those evocative of personified violence such as strangling, war, slash and slam. Third, both the 'Against' and 'For' cases drew upon the explanatory power of the personified metaphor of violence, although the personified metaphors used in support of the pro-regulation case were infrequent. Fourth, the metaphor clusters suggest an existential struggle played out publicly via two contending narrative arcs that shape the representation of the 'Against' and 'For' cases. On the one hand, for example, the Australian Industry Group's chief executive, Innes Willox, described environmental regulation as a 'brake' on progress and that business demanded regulations be 'streamlined'. Similarly, Gillard described environmental regulation as 'undergrowth', while the Coalition claimed these regulations were 'strangling' projects. Conversely, and consistent with Hall et al's (2013) 'strategic silence', conservationists - protesting that miners were 'rapacious'-were marginalised. The conservationists' narrative was that regulations protecting Australia's environmental treasures were being 'bulldozed' and icons 'assaulted'. Arguably, therefore, the metaphor clusters were internally consistent with each side as each generated a narrative consistent with Lakoff and Johnson's 'metaphorical entailment' (1980, p. 97).

Fifth, and perhaps most importantly, personified metaphor uses such as 'strangling', 'choking' and 'stifling' anthropomorphises the abstract concept of 'green tape' as an enemy threatening business, jobs and consumers. According to Lakoff and Johnson (1980), personified metaphors cue consumers' reactions which, in a liberal democracy, legitimise government intervention.

\section{Discussion}

The manner in which metaphor clusters worked together in AAP and agendasetting newspapers during the 'green tape' dispute of 2012 parallels the rhetorical 'method in the metaphor' phenomenon (Bates, 2004). In short, journalists wrote their own personified metaphors into the 'green tape crisis' using such terms as 'war', 'strangling', 'stifling', 'tortuous' and 'streamline'. Critically, party leaders recycled these metaphors and allowed news reports to attribute them as leaders' own terms. This suggests influential journalists possess the power, via their news copy, to cue leaders in metaphor use which, in turn, allows influential journalists to participate in the shaping of public policy. Critically, no converse examples were found of journalists using metaphors in their own words in support of the pro-regulation 'For' case. 
This evidence suggests journalists used the personified metaphor of violence, especially in headlines and lead paragraphs, to simplify for readers a complicated matrix of claim and counter-claim. Importantly, leaders' metaphors supporting the 'Against' case appeared in quotes; a practice consistent with press norms (Whitaker, Ramsey \& Smith, 2013). However, content analysis found that conservative premiers, the federal Labor leadership, multinationals BHP and Rio Tinto, business pressure groups, and the South Australian Labor Premier dominated the debate through their articulation of the 'Against' case - one opposed by Greens leaders and, to a lesser extent, federal Labor Environment Minister Tony Burke. Importantly, based upon the relative frequency of metaphorical support provided to these protagonists, the frequency of deregulatory 'Against' case metaphors significantly outnumbered those 'For'.

Interviewee quotes are potentially powerful persuasion tools for readers, especially in stories without balanced quotes (Gibson, Hester \& Stewart, 2001, p. 67). Crucially, in our sample where pejorative metaphors (18.5 percent), euphemistic metaphors (14.5 percent) and 'Against' case direct quote metaphors (14 percent) are totalled, we find almost half (47 percent) of metaphor use in journalists' copy occurred in a manner designed to attract readers' attention at a deep conceptual level: via metaphor and interviewee quotes. Crucially, this 47 percent of metaphoric language was employed by the dominant deregulatory 'Against' side that sought Commonwealth withdrawal from major project approvals; a withdrawal critiqued by the Wentworth Group of Concerned Scientists (WGCS, 2012). This evidence indicates business pressure groups used their power to publicly warn that 'red tape' threatened major project investment, and the taxonomies suggest key elements of the Fourth Estate provided a rationale for the preferred solution of business and government, surprisingly, via journalists' own vivid metaphor. It appears news outlets set the agenda and normalised the 'green tape' term, with the consequent use of personified and euphemistic metaphor providing a public rationale for the bargain publically struck at the Forum. In sum, the landmark plan for the Commonwealth to withdraw from significant environmental oversight - the terms of which were dealt with in secret between the BCA and the Prime Minister's office and only announced at the Forum - was enveloped in metaphoric justification (substantially in journalists' own words) by some news outlets the day prior to, and after, the Forum(2). This finding lends urgency to calls by international communication scholars to develop 'carefully researched metaphor', or counter-metaphors, to bridge media fragmentation and overcome partisan identity in climate change news (Nisbet, 2009, p. 15; Painter, 2013, p. 10).

Second, the Fourth Estate ideally functions as a scrutineer of government and business power. But this research offers evidence that many news outlets ignore Tony Koch's (Healy, personal communication, 2016) warning to report- 
ers not to get 'too close to the animals in the cages', that is, their sources. In the 'green tape' sample of 2012, for example, some journalists regurgitated and embellished authorities' economic messaging in a way that wholly or partially ignored environmental and health risks. A significant paradox of this finding is that those charged with defending the Fourth Estate, at least in terms of 'green tape' reporting, have been at least partly complicit in undermining Fourth Estate principles of neutrality and objectivity.

\section{Conclusion}

This research offers scholarship key findings on the political communication of major resource projects, and especially on the role of metaphors used to justify reductions in environmental regulation. This research also offers original taxonomies that deliver new metaphor clusters, based upon authoritative field theory, and a study of existing metaphor clusters in environmental news reporting overseas. The research aligns with Bourdieu's (2001) 'evil circle of information' model — where 'journalists manipulate as much as they are manipulated' - in demonstrating how metaphor use in journalists' copy can appeal to readers on a deep conceptual level while, concomitantly, tacitly supporting the commercial interests of major project proponents. Given journalists are reporting at a time of heightened environmental risk, the authors urge further research into metaphoric language in the news media to better understand the shaping of public narratives and, in turn, contentious public policy.

\section{Notes}

1. The addition of euphemism stems from Bourdieu's emphasis on the role of euphemism in discourse, particularly the concern to 'speak well' and 'speak properly' to respond to the requirements of the market (Bourdieu in Matheson, 2003, p 16).

2. Given mitigating factors such as house style and 'public idiom', the authors make no claims about the conduct of individual reporters. Indeed, as Bourdieu (2001, p. 246) points out, 'the further you get in the analysis of a given milieu, the more likely you are to let individuals off the hook'.

\section{References}

Agius, K. (2012, April 20). Green tape slashed under Coalition plan. AAP.

Anderson, K. (2002). Hillary Rodham Clinton as 'Madonna': The role of metaphor and oxymoron in image restoration. Women's Studies in Communication, 25(1), 1-24.

Antilla, L. (2005). Climate of skepticism: US newspaper coverage of the science of climate change. Global environmental change, 15(4), 338-352.

Aristotle, (1991). The art of rhetoric. Harmondsworth, UK: Penguin.

Bacon, W., \& Nash, C. (2012). Playing the media game: The relative (in)visibility of coal industry interests in media reporting of coal as a climate change issue in Australia. Journalism Studies, 13,(2), 243-258. 
Balogh, S. Greens, business divide over Libs one-stop-shop. (2012, April 21). The Australian, p. 2.

Bates, B. (2004). Audiences, metaphors, and the Persian Gulf war. Communication Studies, 55(3), 447-463.

Bourdieu, P. (2001). Television. European Review, 9(3), 245-256.

Bourdieu, P. (2005). The political field, the social science field, and the journalistic field. In R. Benson \& E. Neveu, (Eds.), Bourdieu and the journalistic field, (pp. 29-47). Cambridge, UK: Polity.

Boykoff, M, \& Boykoff, J. (2004). Balance as bias: Global warming and the US prestige press. Global Environmental Change, 14(2), 125-136.

Bradbury, D. (2012). Business leaders to join new deregulation dialogue. [Press release]. Brough, M. (1999). A lost cause? Representations of Aboriginal and Torres Strait Islander health in Australian newspapers. Australian Journal of Communication, 26(2), 89-98.

Brummett, B. (2003). The world and how we describe it: Rhetorics of reality, representation, simulation. Praeger Publishers.

Burke, R. (2002). Invitation or invasion? The 'family home' metaphor in the Australian media's construction of immigration. Journal of Intercultural Studies, 23(1), 59-72.

Business Council of Australia. (2012, April). Discussion paper for COAG Business Advisory Forum. Retrieved from www.bca.com.au/newsroom/discussion-paper-forthe-coag-business-advisory-forum

COAG Business Advisory Forum Communiqué (2012, April 12). Commonwealth. Retrieved from www.coag.gov.au/node/313\#BAF

Crowe, D., \& Hepworth, A. (2012, April 12). PM tells premiers to cut green tape to free capital, The Australian, p 6.

Dayrell, C., Caimotto, M., Muller, M., \& Piao, S. (2016). Discourses around climate change in the news media. Paper presented in Corpora and Discourse International Conference.

De Vreese, C. (2012). New avenues for framing research. American Behavioral Scientist, $56(3), 365-375$.

Doctors for the Environment Australia (2013). The health factor: ignored by industry, overlooked by government. Submission to Commonwealth's inquiry into Major Project Development assessments. College Park, South Australia.

Entman, R. (1993). Framing: Toward clarification of a fractured paradigm. Journal of Communication, 43(4).

FOI/2015/240. Correspondence between Department of the Prime Minister and Cabinet and Business Council of Australia regarding Commonwealth oversight of environmental approvals under the Environment Protection and Biodiversity Conservation Act 1999. [Disclosure log]. Available at www.dpmc.gov.au/government/departmentalfoi-disclosure-logs

Fraser, S. (2006). Speaking addictions: Substitution, metaphor and authenticity in newspaper representations of methadone treatment. Contemporary Drug Problems, 33, 669.

Gibson, R., Hester, J., \& Stewart, S. (2001). Pull quotes shape reader perceptions of news stories. Newspaper Research Journal, 22(20, 66-78.

Gibson, T., Craig, R, Harper, A., \& Alpert, J. (2015). Covering global warming in dubious times: Environmental reporters in the new media ecosystem. Journalism, 17(4), 417-434. doi: 10.1177/1464884914564845

Hall, S., Critcher, C., Jefferson, T., Clarke, J., \& Roberts, B. (2013). Policing the crisis: Mugging, the state and law and order. London, UK: Palgrave Macmillan.

Harris, P., Harris, E., Thompson, S., Harris-Roxas, B., \& Kemp, L. (2009). Human health and wellbeing in EIAs in New South Wales: auditing health impacts within 
environmental assessments of major projects. Environmental Impact Assessment Review, 29, 310-318.

Healy, G. (2016). Personal communication with Tony Koch, Brisbane, Queensland.

Hepworth, A., (2012, April 11). Companies urge war on environmental 'green tape'. The Australian. $\mathrm{p} 1$.

Herrick, C. \& Jamieson, D. (2001). Junk science and environmental policy: Obscuring public debate with misleading discourse. Philosophy \& Public Policy Quarterly, 21(2/3), 11-16.

Jacques, P., Dunlap, R., \& Freeman, M. (2008). The organisation of denial: Conservative think tanks and environmental skepticism. Environmental politics, 17(3), 349-385.

Johnson, C. (2012, April, 13). PM sells skills as red tape targeted. Canberra Times, p. 4.

Krennmayr, T., (2015). What corpus linguistics can tell us about metaphor use in newspaper texts. Journalism Studies, 16(4), 1-17.

Lakoff, G., \& Johnson, M. (1980). Metaphors we live by. Chicago, IL: University of Chicago Press.

Lakoff, G. (2010) Why it matters how we frame the environment. Environmental Communication, 4(1), 70-81.

Livesey, S. (2002). Global warming wars: Rhetorical and discourse analytic approaches to ExxonMobil's corporate public discourse. Journal of Business Communication, 39(1), 117-146.

Luokkanen, M., Huttunen, S., \& Hilden, M. (2014). Geoengineering, news media and metaphors: Framing the controversial. Public Understanding of Science, 23(8), 966-981.

Macintosh, A. (2009). The Environment Protection and Biodiversity Conservation Act 1999 (CT): an evaluation of its cost-effectiveness. Environmental and Planning Law Journal, 26(5), 337-362.

Marsh, D., Lewis, C., \& Chesters, J. (2014). The Australian mining tax and the political power of business. Australian Journal of Political Science, 49(4), 711-725.

Matheson, D. (2003). Scowling at their notebooks How British journalists understand their writing. Journalism, 4(2), 165-183.

McCright, A., \& Dunlap, R. (2000). Challenging global warming as a social problem: An analysis of the conservative movement's counter-claims. Social problems, 47(4), 499-522.

McGaurr, L., Lester, L., \& Painter, J. (2013). Risk, uncertainty and opportunity in climate change coverage: Australia compared. Australian Journalism Review, 35(2), 21-33.

McGrath, C. (2014). One stop shop for environmental approvals a messy backward step for Australia. Environmental and Planning Law Journal, 31(3), 164-191.

McKay, F., Thomas, S., \& Blood, R. (2011). 'Any one of these boat people could be a terrorist for all we know!' Media representations and public perceptions of 'boat people' arrivals in Australia. Journalism, 12(5), 607-626.

McKnight, D., \& Hobbs, M. (2013). Public contest through the popular media: The mining industry's advertising war against the Australian Labor government. Australian Journal of Political Science, 48(3), 307-319.

McLachlan, R. (2013). Deep and persistent disadvantage in Australia. Productivity Commission Staff Working Paper. Canberra, Commonwealth.

Miles, M., Huberman, A., \& Saldana, J. (2013). Qualitative data analysis: A methods sourcebook. London, UK: SAGE Publications.

Morris, S \& Ludlow, M. (2012, April 21). Abbott plays catch-up. Australian Financial Review, p. 5.NASA, October, 2016. NASA analysis finds warmest September on record by narrow margin. Retrieved from http://data.giss.nasa.gov/gistemp/news/20161017/

Nerlich, B. (2010). 'Climategate': Paradoxical metaphors and political paralysis. Environmental Values, 419-442. 
Nisbet, M., \& Huge, M. (2006). Attention cycles and frames in the plant biotechnology debate managing power and participation through the press/policy connection. The Harvard International Journal of Press/Politics, 11(2), 3-40.

Nisbet, M. C. (2009). Communicating climate change: Why frames matter for public engagement. Environment: Science and Policy for Sustainable Development, 51(2), 12-23.

Noble, G., \& Poynting, S. (2003). Acts of war: Military metaphors in representations of Lebanese youth gangs. Media International Australia incorporating Culture and Policy, 106(1), 110-123.

Onwuegbuzie, A., \& Leech, N. (2005). On becoming a pragmatic researcher: The importance of combining quantitative and qualitative research methodologies. International Journal of Social Research Methodology, 8, 375-387.

Onwuegbuzie, A., \& Collins, K. (2007). A typology of mixed methods sampling designs in social science research. The qualitative report, 12(2), 281-316.

Osborne, P. (2012, April 13). Training, green tape moves at COAG. AAP.

Osborne, P. (2012, April 13). COAG to reform environmental rules. Cut green tape in development. The Advertiser, p 28.

Painter, J. (2013). Climate change in the media: Reporting risk and uncertainty. IB Tauris.

Pan, Z., \& Kosicki, G. (1993). Framing analysis: An approach to news discourse. Political communication, 10(1), 55-75.

Pearse, G., Burton, B., \& McKnight, D. (2013). Big coal: Australia's dirtiest habit. Sydney, NSW: University of New South Wales.

Petersen, J. H. (2003). Lippmann revisited: A comment 80 years subsequent to 'public opinion'. Journalism, 4(2), 249-259.

Plato, (380BCE). Gorgias. [J. Benjamin, Trans] Retrieved from http://classics.mit.edu/ Plato/gorgias.html

Rapp, C. (2010). 'Aristotle's Rhetoric', The Stanford Encyclopedia of Philosophy, Edward N. Zalta (ed.). Retrieved from: https://plato.stanford.edu/archives/spr2010/ entries/aristotle-rhetoric/>.

Robie, D. (2014). 'Carbon colonialism': Pacific environmental risk, media credibility and a deliberative perspective. Pacific Journalism Review, 20(2), 59.

Rowinski, P. (2014). Euroscepticism in the Berlusconi and Murdoch press. Journalism, 17(8), 979-1000.

Rudd, K. (2007). Climate change: The great moral challenge of our generation. LaborTV.

Saxton, A. (2003). 'I certainly don't want people like that here': The discursive construction of asylum seekers. Media International Australia incorporating Culture and Policy, 109(1), 109-120.

Schlesinger, M., \& Lau, R. (2000). The meaning and measure of policy metaphors. American Political Science Review, 94(3), 611-626.

Shepherd, T. (2012). Opening statement at the announcement of the new Business Advisory Forum. [Press release]. Retrieved from http://www.bca.com.au/media

Shepherd, T. (2012). Statement by BCA President Tony Shepherd at the COAG Business Advisory Forum Media Conference. [Press release]. Retrieved from www.bca.com. $\mathrm{au} / \mathrm{media}$

Stocker, T., Qin, D., Plattner, G., Alexander, L., Allen, S., Bindoff, N. \& Forster, P. (2013). Technical summary. In Climate change 2013: The physical science basis. Contribution of Working Group I to the Fifth Assessment Report of the Intergovernmental Panel on Climate Change (pp. 33-115). Cambridge, UK: Cambridge University Press. 
Stockwell, S. (2005). Political campaign strategy: Doing democracy in the 21st century. Kew: Australian Scholarly Publishing.

Stone, O., \& Kuznick, P. (2013). The untold history of the United States. New York, NY: Simon and Schuster.

Taylor, L., and Coorey, P. (2012, April 12). Premiers to slash green tape, inefficient climate schemes. The Sydney Morning Herald, p. 5.

Tingle, L. (2012, April 14). Greens to veer left under Milne. Australian Financial Review, p. 2.

Thibodeau, P., \& Boroditsky, L. (2011). Metaphors we think with: The role of metaphor in reasoning. PloS One, 6(2), e16782.

Toncar, M., \& Munch, J. (2003). The influence of simple and complex tropes on believability, importance and memory. Journal of Marketing Theory and Practice, 11(4), 39-53.

Tranter, B., \& Booth, K. (2015). Scepticism in a changing climate: a cross-national study. Global Environmental Change, 33, 154-164.

Trumbo, C. (1996). Constructing climate change: claims and frames in US news coverage of an environmental issue. Public Understanding of Science, 5(3), 269-284.

Tsokhas, K. (1998). The Australian Mining Industry Council, 1967-75. Business History, 40, (3), 104-128.

Walther, G., Hughes, L., Vitousek, P., \& Stenseth, N. (2005). Consensus on climate change. Trends in Ecology \& Evolution, 20(12), 648-649.

Watts, R. (2003). 'Headlining heroin': Policy change and reporting the heroin problem. Media International Australia incorporating Culture and Policy, 108(1), 67-81.

Wentworth Group of Concerned Scientists (2012). Statement on changes to Commonwealth Powers to protect Australia's environment. Retrieved from http://wentworthgroup.org

Williams, P. D. (2008). The 2007 Australian federal election: The story of Labor's return from the electoral wilderness. Australian Journal of Politics and History, 54(1), pp. 104-125.

Whitaker, W., Ramsey, J., \& Smith, R. (2013). Media Writing: print, broadcast and public relations. London, UK: Routledge.

Woodward, A., Smith, K., Campbell-Lendrum, D., Chadee, D., Honda, Y., Liu, Q., \& Confalonieri, U. (2014). Climate change and health: on the latest IPCC report. The Lancet, 383(9924), 1185-1189.

Yazahmeidi, B., \& Holman, C. (2007). A survey of suppression of public health information by Australian governments. Australian and New Zealand Journal of Public Health, 31(6), 551-557.

Guy Healy is a PhD candidate at Queensland University of Technology Creative Industries. He has a BA from Monash (Clayton), and a BJourn Honours First Class from Griffith University. Healy is a former journalist from The Australian, but has also freelanced for BBC Wildlife, Australian Geographic, The Guardian and The Saturday Paper.

guy.healy@gmail.com 
Dr Paul Williams is a senior lecturer in the Department of Humanities at Griffith University, Nathan. He has research expertise in Queensland state politics, Australian national politics, election campaigns and the media, and political leadership, and government-business relations.

\section{AUT COMMUNICATION STUDIES, TELEVISION \& SCREEN PRODUCTION}

A focus on real people to tell their stories

The ability to make exciting and innovative documentaries and screen productions that tell a good story is at the heart of undergraduate and postgraduate study at AUT.

The papers cover producing, directing, script writing, camera and sound recording, editing, production management and interviewing. They are taught by passionate, award-winning practitioners.

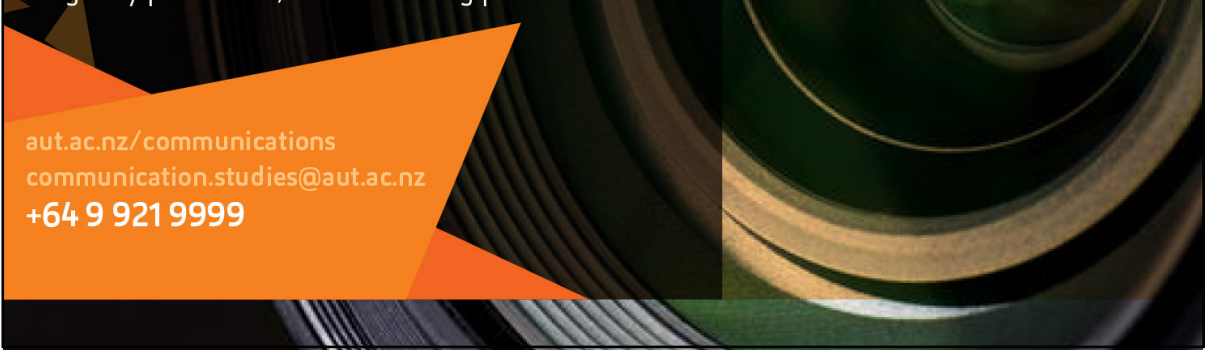

